\title{
釜石鉱山
}

\section{Kamaishi Mine}

\section{1. 緒言}

釜石鉱山は鉄鉣山として本邦最大の規模を有し，鉄鉱 石のほかに銅鉱石，石灰石の採掘を行なつている。年間 生産高はつぎの如く( 41 年度実績)銅鉣山としても国内有 数の規模である。鉄精鉱 $504,118 \mathrm{t}, \mathrm{Fe} 59.32 \%$ ，銅精鉱 $29,203 \mathrm{t}, \mathrm{Cu} 19.17 \%$ (銅量 $5,597 \mathrm{t}$ ), 石灰石 $180,964 \mathrm{t}$ 。

位置：当鉱業所は岩手県釜石市甲子町大橋にあり,
正会員三宅威 男*

Takeo MIYAKE 釜石港西方 $16 \mathrm{~km} ，$ 東北本線花巻駅 東方約 $70 \mathrm{~km}$ で，釡石線陸中大橋駅 より徒歩約10分程である。採掘鉱区 30 鉱区 $(469,226$ アール) 試掘鉱区 27

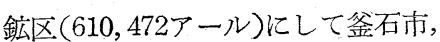
遠野市および気仙郡住田町にまたが つている。

沿革：伝説尤ば当鉱山の発見 は古く享保年間（1716 1736) であ り，文政12年頃(1822)に稼行された といわれているが，明治以降政府工 部省直営田中鉱山株式会社, 釜石鉱 山株式会社，等を経て昭和14年当社 に移った。明治 25 年以降，昭和 41 年 度までの間の累計粗鉱生産量は, 約 3, 200万 t である。

\section{現 状}

第1表 出鉱量と出鉱品位

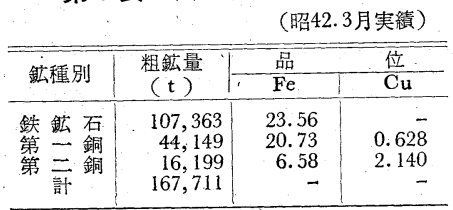

第 2 表 従業員 (鉱山部一鉱床探査 •採鉱・選鉱部門）（昭42.3月実績）

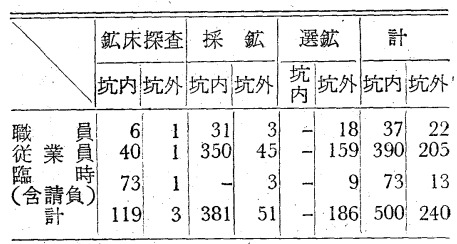

*.日鉄釷業株式会社釜石鉱業所

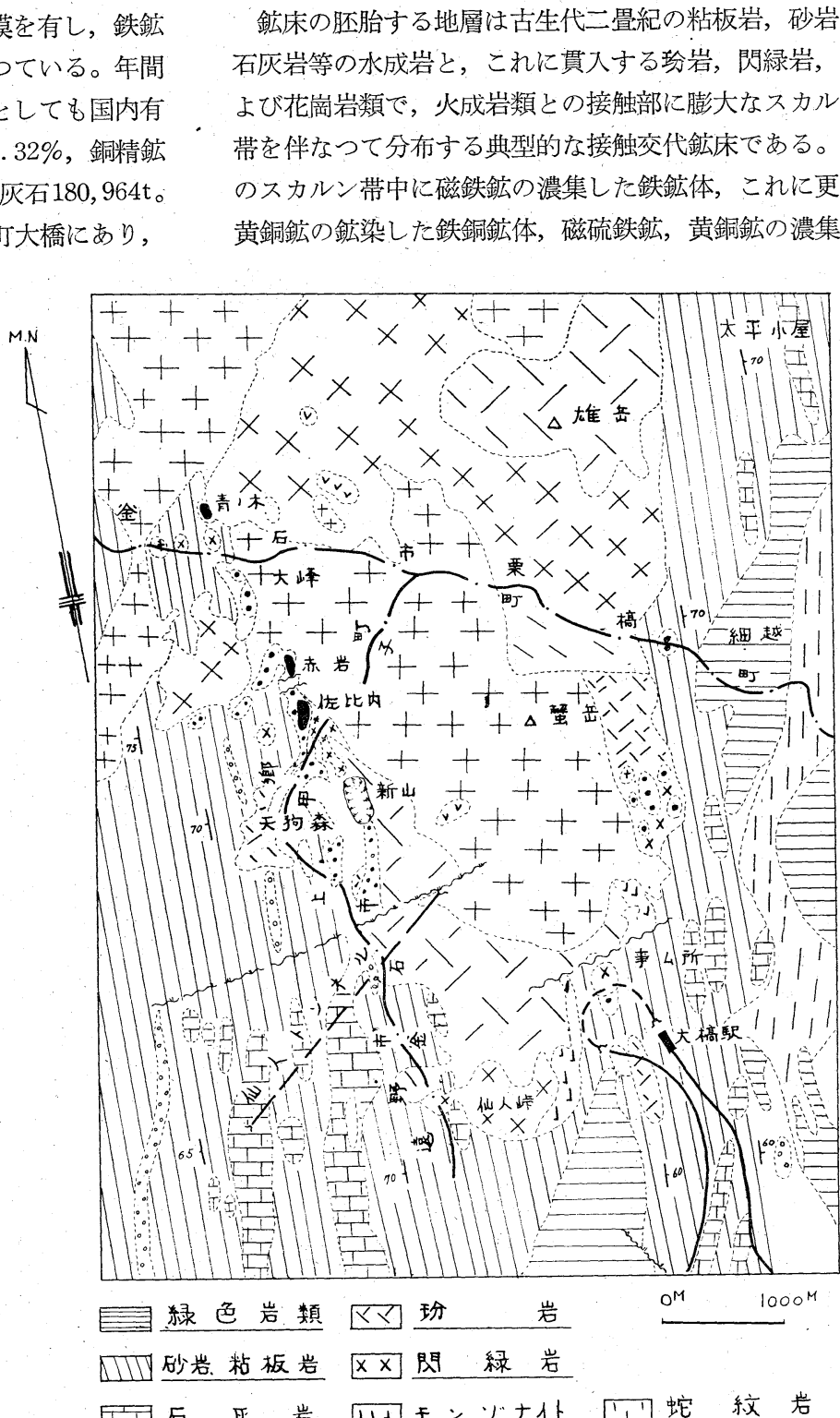

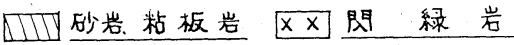

开正岩 円1

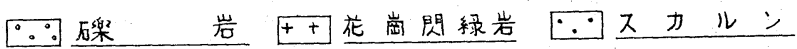

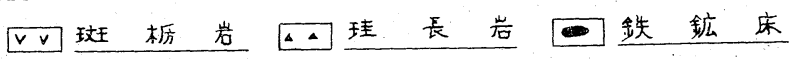

第1図、釜石鉱山地質図 
た銅鉱体の 3 種がある。これら各種の鉱体はスカルン帯 中で火成岩側より堆積岩側への明膫な帯状の分布を示し 鉄鉱体はその最も火成岩側にザクロ石系のスカルンを脈 石として分布，その延長の端末部では磁鉄鉱を減ずると ともに黄銅鉱の鉱染を増し鉄銅鉱体となり，堆積岩（と くに石灰岩）側には銅鉱体が輝石，角閃石系のいわゆる 緑色スカルンを伴なつて分布している。鉱床は北から青 の木, 大峰, 赤岩, 佐比内, 新山, 滝之沢, 沓掛, 誢, 大仙，等の鉱床群がほぼ南北酒列する他，東部には小 規模な, 高前, 細越, 前山, 等の東列鉱床群が存在す る。鉱体は㧍おむ斿不規則塊状で大きさも一定せず鉄銅 の品位も場所により，かなりの変化がある。現在稼行中 の主要鉱体の規模，品位，形状はつぎのようである。

第 3 表 主要鉱体別の規模・品位・形状

\begin{tabular}{|c|c|c|c|c|c|c|c|c|}
\hline \multirow{2}{*}{ 鈗種 } & \multirow{2}{*}{ 鉣床名 } & \multicolumn{3}{|c|}{ 規 模 } & \multicolumn{2}{|c|}{ 品 位 $(\%)$} & \multirow{2}{*}{ 形 状 } & \multirow{2}{*}{ 平均傾斜 } \\
\hline & & $\begin{array}{l}\text { 走向 } \\
(\mathrm{m})\end{array}$ & 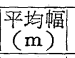 & $\begin{array}{l}\text { 深度 } \\
(\mathrm{m})\end{array}$ & $\mathrm{Fe}$ & $\mathrm{Cu}$ & & \\
\hline 鉄 & $\begin{array}{ll}\text { 新 } \\
\text { 佐 比内 } \\
\text { 尖 }\end{array}$ & $\begin{array}{l}660 \\
250 \\
240\end{array}$ & $\begin{array}{r}100 \\
40 \\
100\end{array}$ & $\begin{array}{l}450 \\
400 \\
250\end{array}$ & $\begin{array}{l}26.1 \\
28.1 \\
28.4\end{array}$ & $\begin{array}{l}0.09 \\
0.13 \\
0.09\end{array}$ & $\begin{array}{l}\text { 塊 状 } \\
\text { 状ンズ状 } \\
\text { 塊 状 }\end{array}$ & $\begin{array}{l}70^{\circ} \sim 90^{\circ} \\
70^{\circ} \sim 90^{\circ} \\
70^{\circ} \sim 90^{\circ}\end{array}$ \\
\hline 鉄銅 & $\mid \begin{array}{ll}\text { 新山第 } 1 \\
\text { 第 } & 6 \\
\text { 第 } & 7\end{array}$ & $\begin{array}{l}370 \\
100 \\
300\end{array}$ & $\begin{array}{l}80 \\
80 \\
15\end{array}$ & $\begin{array}{l}400 \\
150 \\
350\end{array}$ & \}$_{33.5}^{24.3}$ & $\begin{array}{l}0.45 \\
0.73\end{array}$ & $\left\{\begin{array}{l}\text { 坥 }{ }^{\text {状 }} \\
\text { レンズ状 }\end{array}\right.$ & $\begin{array}{l}70^{\circ} \sim 90^{\circ} \\
70^{\circ} \sim 90^{\circ} \\
30^{\circ} \sim 90^{\circ}\end{array}$ \\
\hline 銅 & \begin{tabular}{|l} 
新山第 \\
2 \\
第 \\
第 \\
第 \\
r \\
4 \\
5
\end{tabular} & $\begin{array}{l}500 \\
150 \\
400 \\
200\end{array}$ & $\begin{array}{r}30 \\
5 \\
10 \\
5\end{array}$ & $\begin{array}{l}100 \\
100 \\
100 \\
100\end{array}$ & $\left\{\begin{array}{l}13.0 \\
8.8\end{array}\right.$ & $\begin{array}{r}3.68 \\
2.79\end{array}$ & $\begin{array}{c}\text { レンズ状 } \\
\text { ”! } \\
\text { I" }\end{array}$ & $\mid \begin{array}{l}30^{\circ} \sim 90^{\circ} \\
10^{\circ} \sim 40^{\circ} \\
70^{\circ} \sim 90^{\circ} \\
50^{\circ} \sim 70^{\circ}\end{array}$ \\
\hline
\end{tabular}

\section{探鉱の概要}

探鈗の範囲はかなり広いが，現在大峰鉱床付近，佐比 内 大峰間, 新山西盤の銅鉱床, 新山深部, 沓掛, 誢, 大仙地区，等を探查の重点としている。方法としてはこ れらの地域基幹探鉱坑道を掘進しこれを基地として構 造試錐，新鉱床探査試錐を実施し発見された鉱体に対し ては開坑がやや進んだ段階で精密な鉱体試錐を実施する こととしている。物理探鉱は磁力探鉱を主として坑内外 にわたり実施しているが，最近は試錐孔内磁力探查計を 導入して成果を期待している。このほか I P 法による探 鉱も実施している。探鉱坑道は大部分機械化し，レッグ ドリル，ローダーバッテリー機関車の組合せによる掘進 を実施し，女るいはバンカートレーンの導入により急速 に能率が上抙している。試錐は大型機械（能力200 500 m) の電動機12台, $100 \mathrm{~m}$ 能力の空動機 8 台を使用し, ワイヤーライン方式および空動機の ワンマン操作等に より実施している。年度別実績は，つぎのとおりであ る。

第 4 表 年度別試錐，探鉱坑道実績表

\begin{tabular}{|c|c|c|c|c|c|}
\hline & 試錐㻕進 & $\begin{array}{l}\text { 探鉱坑道 } \\
\text { 掘 }\end{array}$ & & 試錐掘進 & $\begin{array}{l}\text { 探鉣坑道 } \\
\text { 掘 }\end{array}$ \\
\hline $\begin{array}{c}\text { 昭 } 27 \text { 管度 } \\
28 \\
29 \\
30 \\
31 \\
32 \\
33 \\
34\end{array}$ & $\begin{array}{l}3,626 \mathrm{~m} \\
4,826 \\
6,514 \\
5,120 \\
6,448 \\
7,146 \\
7,776 \\
7,626\end{array}$ & $\begin{array}{l}1,372 \mathrm{~m} \\
2,090 \\
1,377 \\
1,025 \\
2,307 \\
3,103 \\
1,310 \\
958\end{array}$ & $\mid \begin{array}{l}\text { 炤. } 35 \text { 年度 } \\
36 \\
37 \\
38 \\
39 \\
40 \\
41\end{array}$ & $\begin{array}{l}12,270 \mathrm{~m} \\
13,221 \\
13,856 \\
15,144 \\
20,182 \\
28,014 \\
30,771\end{array}$ & $\begin{array}{l}1,078 \mathrm{~m} \\
873 \\
3,158 \\
4,023 \\
4,767 \\
5,874 \\
6,261\end{array}$ \\
\hline
\end{tabular}

\section{3. 採掘 法}

\section{$3 \cdot 1$ 採掘法の変せんおよびその採用理由}

当鉱山の採掘法についていままで数回発表されている ので変せんについて概要を説明する。かつては 1 鉱画高 さ $25 \mathrm{~m}$ とし鉱床全面に亘つて幅 $20 \mathrm{~m}$ を 1 切羽として高さ $10 \mathrm{~m}$ の空洞掘を実施していたが可採率の低いこと，採鉱 能率の低いこと，鉱床の規模に相応する出鉣を期待し得 ないこと，等により大正 14 年より 1 鉱画高さ $50 \mathrm{~m}$ の「シ ニリンケージ法」を計画し，昭和 5 年より実施してきた が, 戦後タングステンカーバイドビットの出現と長孔穿 孔技術の進歩により「サブレベル・ストーピング法」を 採用して現在に至つている。サブレベル，ストーピング 法の利点とされる点は,

1. 新鉱床発見による早期採掘出鉱をなし得る。

2. 切羽分集約される。

3. 切羽貯鉱を必要としない。

4. 採掘能率の向上，大型化が可能である。

5. 保安上直接切羽面にさらされず安全である。 等である。

\section{$3 \cdot 2$ 採掘法に関係ある母岩と鉱床の状況}
A) 母岩
1）岩石の種類および比重

㸮岩，花崗閃緑岩，石灰岩，粘板岩，柘榴石，等スカ ルン鉱物, “比重 $2.9 \sim 3.0$

2）採鉱上影響を打上ぼす諸性質 
a）石目の有無とその状態

石目あるも，それ程大きい影響をおよぼすまでに至ら ない。

b ）断層または褶曲の有無とその状態

断層：新山には余り見られず，佐比内には大きなものが あり，鉱床のずれが見られ傾斜は $60^{\circ} \sim 70^{\circ}$ である。

褶曲：余り見られず

c）盤と鉱石との境界の状態

不規則

d）岩盤の硬軟の程度，含水状態

堅硬，含水状態は一部に若干あり, $\mathrm{pH} 7.0$ 程度

B) 鉱 床

1）貫入岩：坋岩，後期坋岩が赤岩に，半花崗岩が大 峰に見られる。

挾み：新山の下端部に食い残し玢岩が不規則にあり。

2）品位分布の規則性

不規則なるも鉄鉱床，鉄銅鉱床は東盤側が，銅鉱床は西 盤側石灰岩との接触部が高品位を示す。

3）鈗石の比重（品位と比重との関係）

鉄 $\mathrm{Fe} 20 \%$ で $3.56,30 \%$ で $3.78,40 \%$ で 4.03

銅 $\mathrm{Cu} 1 \%$ で $3.28,3 \%$ で 3.35

4）鉱床の形状と規模

(前述)

5）走向および傾斜方向の膨縮の有無 レンズ状に膨縮あり。

6）採鉱上影響をおよぼす諸性質

a）穿孔の難易: 難

Relatine Drillability 0.375

Relatine Abrasion Characteristic 1.04

イインガソー 社の調查資 料上り

b）発破の効き：良

c）鉱石の破砕性：堅硬にしてとくに銅鉱床において 演悪い

d）地表宿落：新山のみ戦時中の乱掘により宿没す

e ）湧水の有無：一部に見られるがほとんど影響な L

f）地表から採掘切羽までの深度

新山，佐比内，鉄釷床は，露頭より採掘開始。

大峰鉄鉱床は，現在のところ約 $260 \mathrm{~m} 。$

新山銅鉱床法，約 $200 \mathrm{~m}$ 。

\section{$3 \cdot 3$ 現在の採掘法の種類}

現在採用している主なる採掘法は

露天掘 : 佐比内鉱床露頭部分を実施中

坑内掘：(1) 長孔式サブレベルストーピング法……鉄鉱 床，鉄銅鉱床

（2）下向半長孔式サブレベルストーピング法 $\cdots$ …銅鉱床であり。

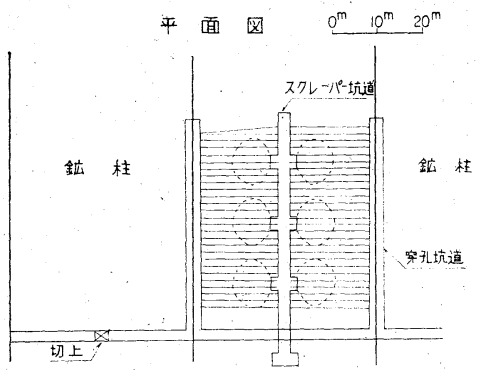

断面国

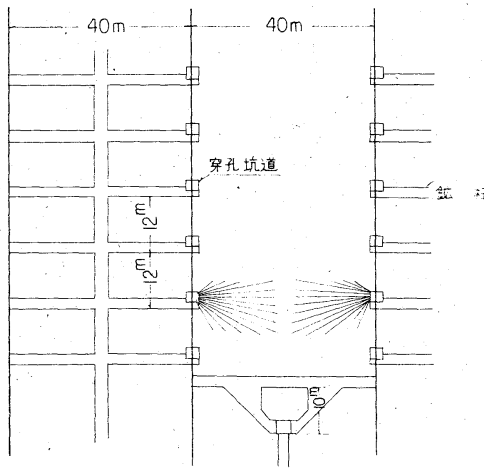

第 3 図

大峰鉣床 No. $5 \mathrm{~S} \mathrm{C}$ 採掘説 明図

下向半長孔式サブレベルストーピング法は，粗鉣洒值が 高く，鉱床の幅が比較的狭く，ま盤祭をてい教いに採 掘し，採掘実收率の向上，ズリ混入率の低下老目的をせ ねばならない銅鉱床に採用している。したがうて若干能 率が犠牲になつている。

\section{4 主な採掘法の説明}

坑内採掘は 1 次採掘と 2 次採掘々汇区別さ机，1 次採 掘は，垂直および我平鉱柱を規則的に残してサブレベル ストーピングを実施し，2 次採掘は，その鍍柱をブロッ ク毎に一斉に採掘するものである。現在実施中の代表的 な採掘法を説明する。

大峰鉄鉱床の長孔式ザブレベルストーピンゲ法（第 3 図参照)：1 次採掘の際に鉱柱幅，採掘幅を之れぞれ $40 \mathrm{~m}$ とし走向方向と直交するようにとり，鉱体の最下底 にスクレーパー坑道 $(2.5 \mathrm{~m} \times 3.0 \mathrm{~m})$ を設ける。スクレー パー坑道を保護する屋根の厚さを $10 \mathrm{~m}$ とその屋根のレ ベルまで，漏斗状の鉱石拢き出し口(ドローホール)をス クレーパー坑道の左右両側にそれぞれ $2 \sim 3$ 個所安設け, 屋根のレベルで採掘区域全面にわたつて高さ $2.1 \mathrm{~m}$ のア ンダーカットをする。各サブレベルの連絡坑道 $(2.1 \mathrm{~m} \times$ $1.8 \mathrm{~m})$ は鉱柱内に設ける人道切上 $(2.7 \mathrm{~m} \times 1.5 \mathrm{~m})$ 上り高 さ $12 \mathrm{~m}$ 間隔に掘進し，採掘区画の鉱柱際に穿孔坑道 $(3.0$ $\mathrm{m} \times 2.5 \mathrm{~m})$ を設けこれより垂直扇状並列に長孔を穿孔し て，各段每に一斉に発破を行ない採掘する。積込注 $75 \mathrm{H}$ のスクレーパーで直接坑井に搔込んでいる(現在は $125 \mathrm{H}$ スクレーパーを一部で使用中)。各サブレベルの坑道掘 
第 5 表採掘法別出鉱量扣よび切羽数 (昭 42.3 月実績)

\begin{tabular}{|c|c|c|c|c|}
\hline 採掘法の種類 & & 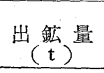 & $\begin{array}{c}\text { 出鉱比率 } \\
(\%)\end{array}$ & 切羽 数 \\
\hline 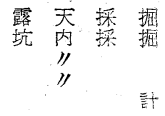 & 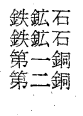 & $\begin{array}{r}32,035 \\
75,328 \\
44,149 \\
16,199 \\
167,711\end{array}$ & $\begin{array}{r}19.1 \\
44.9 \\
26.3 \\
9.7 \\
100\end{array}$ & $\begin{array}{r}1 \\
7 \\
4 \\
7 \\
19\end{array}$ \\
\hline
\end{tabular}

第 6 表 開探鈗出鉱量拉よび陚錐延長（昭42.3月実績）

\begin{tabular}{|c|c|c|c|c|c|}
\hline & \multirow{2}{*}{$\begin{array}{c}\text { 試錐延長 } \\
\text { (m) }\end{array}$} & \multirow{2}{*}{$\begin{array}{c}\text { 探鈗延長 } \\
(\mathrm{m})\end{array}$} & \multicolumn{3}{|c|}{ 出鉱量 $(t)$} \\
\hline & & & 開探鉣 & 採 鉱 & 詝 \\
\hline 42 年 3 月 & 3,152 & 673 & - & - & - \\
\hline
\end{tabular}

進は、TY-24レッグドリル 2 台と 10Pまたは 15Pスク レーパーとの組合せで行なら。能率 $0.5 \mathrm{~m} /$ 工

長孔は，DH-123 J ，ビット $54 \mathrm{~mm} \times$ 型，ロッド $29 \mathrm{~mm}$ 中空六角, 孔列間隔 $2.0 \sim 1.0 \mathrm{~m}$ ，孔の搪りは，孔長 $20 \mathrm{~m}$ で2. $0 \sim 4.0 \mathrm{~m}$, 穿孔能率 $40 \mathrm{~m} /$ 工, 穿孔m当採掘量 $8 \sim 14 \mathrm{t}$ $/ \mathrm{m}$, 火薬装填量 $150 \mathrm{~g} / \mathrm{t}(\mathrm{AN}-\mathrm{F} \mathrm{O}$ 使用率 $95 \%)$, スクレ 一パ-能率 $75 \mathrm{H} 108 \mathrm{t} /$ 工, 二次火薬量, $250 \mathrm{~g} / \mathrm{t}(\mathrm{AN}-\mathrm{F} \mathrm{O}$
使用率 $90 \%$ )。長孔式サブレベル採掘を開始した当初よ り，現在の大峰式に至るまでの改良点としては，

1）一次採掘の際に残す垂直鉱柱（東西両盤にわたる 鉱壁) の幅を充分に大きくした $(10 ， 15 ， 20 ， 40 \mathrm{~m}$ と順 次に)

2） 1 鉱画の高ざ $50 \mathrm{~m} よ り 100 \mathrm{~m}$ にし準備費の節減 を計つた。

3）長孔用さく岩機を順次大型化し，ブースター使用 による能率化を計つた。D-7，DM-34，D-99より現在 は, D H123 J 。

4）穿孔技術および能率向上によりサブレベル垂直間 隔を $7 \mathrm{~m}$ より $12 \mathrm{~m}$ に(現在 $30 \mathrm{~m}$ 準備中), 切羽準備費 の節減を計つた。

5）積込方法は，人力による中段シニート積よりスク レーパー $75 \mathrm{PP}$ に改善したこと, 現在 $125 \mathrm{P}$ スクレーパー を試用中である。

6）シニート抜に伴なら切羽運搬をできる限りなくし スクレーパーによる坑井への直接搔込を実施した。

7）主旨一貫して順次大型化してきたので技術的進歩

第 7 表 採掘法別工程原単位扎よび直接採掘，採鉱費（昭42.3月実績）

\begin{tabular}{|c|c|c|c|c|c|c|c|c|c|c|c|c|c|c|c|c|c|c|c|c|c|}
\hline & \multirow{2}{*}{$\begin{array}{c}\text { 採鉱量 } \\
\mathrm{t} / \text { 月 }\end{array}$} & \multirow{2}{*}{$\begin{array}{l}\text { 充填量 } \\
\mathrm{m}^{3} / \mathrm{t}\end{array}$} & \multicolumn{2}{|c|}{ I } & 数 & \multicolumn{5}{|c|}{ 原 単 位 (粗鉱 $\mathrm{t}$ 当たり) } & \multicolumn{3}{|c|}{ 直接採掘費 $\mathrm{t}$ 当たり } & \multicolumn{4}{|c|}{ 值接採鉱費 $\mathrm{t}$ 当たり } & \multicolumn{4}{|c|}{ その 他 } \\
\hline & & & 採掘 & 充填 & 計 & 工数 & $\begin{array}{l}\text { 爆薬量 } \\
(\mathrm{kg} / \mathrm{t})\end{array}$ & 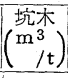 & $\left(\begin{array}{l}\text { 鋼材 } \\
(\mathrm{kg} / \mathrm{t}\end{array}\right)$ & $\left.\begin{array}{c}\text { 電力 } \\
\mathrm{kW} \\
\mathrm{h} / \mathrm{t}\end{array}\right)$ & \begin{tabular}{|c|c|} 
人件 & 物品 \\
$\%$ & $\%$ \\
\end{tabular} & $\begin{array}{l}\text { 究の } \\
\text { 他\% }\end{array}$ & 計 & \begin{tabular}{|c|} 
人件 \\
$\%$
\end{tabular} & $\begin{array}{c}\text { 㸮品 } \\
\%\end{array}$ & $\mid \begin{array}{l}\frac{\gamma}{2} \\
\mid\end{array}$ & 訫 & 人件特 & 物品 & その & 計 \\
\hline 露天採掘鉄鉱石 & 32,035 & - & 415 & - & 415 & 0.013 & * $\begin{array}{l}0.107 \\
0.125\end{array}$ & & & 0.335 & 932.0443 .0 & 2.2 & 100 & & & & & & & & - \\
\hline 坑内採掘鉄鉣石 & 75,328 & - & 1,746 & - & 1,746 & 0.023 & * $\quad 0.487$ & 0.0002 & 0.002 & 0.63 & 258.3 & 2.5 & 100 & & - & & & & & & - \\
\hline 第一銅 & 44,149 & - & 567 & - & 567 & 0.013 & $\begin{array}{l}0.286 \\
0.175\end{array}$ & 0.0004 & 0.045 & 0.3 & 45.652 .6 & 1.8 & 100 & & - & & - & - & - & & - \\
\hline 第二銅 & 16,199 & - & 1,078 & - & 1,078 & 0.067 & $* 0.578$ & 0.0003 & & 0 & $.2|46.6|$ & 0.2 & 100 & & - & - & & - & - & & 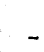 \\
\hline 計 & 167,711 & - & 3,806 & - & 3,806 & $0.023 *$ & 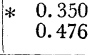 & 0.0002 & 0.013 & 0.4 & 44.553 .7 & 1.8 & & 0 & 2.8 & 8.2 & 100 & & & & - \\
\hline
\end{tabular}

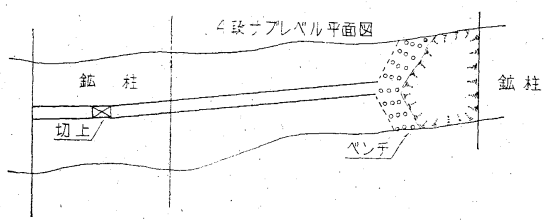

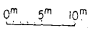
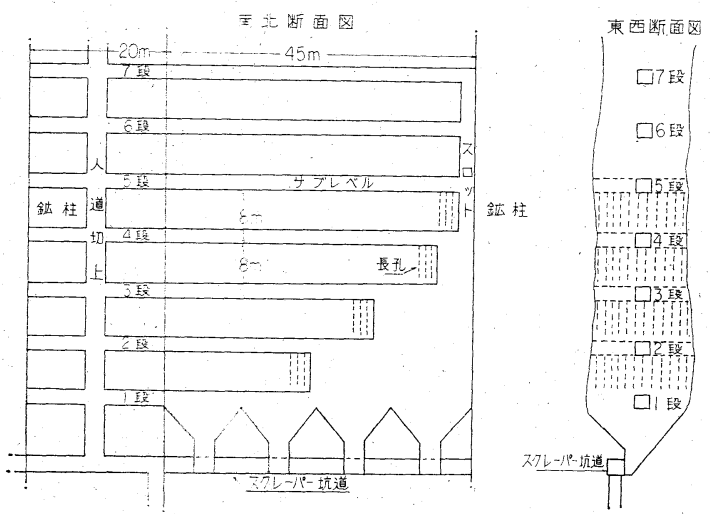

第 4 図第 4 銅鉱床採掘説明図
の遅滞なく AN-FO使用により成果は一段と著しいも のになつた。

第 4 銅鉱体の下向半長孔式サブレベルストーピング法 (第 4 図参照)： 鉱柱を走向方向に直交して幅 $20 \mathrm{~m}$ にと り，採掘幅を $45 \mathrm{~m}$ とし，鉱体の最下底にスクレーパー坑 道を設ける。鉱柱内の人道切上より $8 \mathrm{~m}$ 間隔にサブレベ ル坑道を鉣床内に掘進しつぎの鉱柱側にスロットを設け サブレベル坑道より，スロットに沿つて鉱体幅だけ根切 （高さ $2.1 \mathrm{~m}$ ) をし，幅5〜6mのベンチを造る。このベン チでTY 145またはT Y 150で下向きに $6 \mathrm{~m}$ 前後の半長孔 を穿孔して横払いに発破する。各段の関係は上向き階段 状になるように後退式に採掘する。根切りによつて，ベ ンチを造る際のズリ取りは10H 3 ドラムスラッシャを使 用している。

T Y-145による半長孔

ビット $42 \mathrm{~mm}$ クロス，ロッド $22 \mathrm{~mm}$ 六角中空長さ $1 \mathrm{~m}$ 能率 $9.5 \mathrm{~m} /$ 工, $6 \mathrm{t} / \mathrm{m}$, 使用火薬量 $300 \mathrm{~g} / \mathrm{t}$ 積込スクレーバ 
$20 \sim 30 \mathrm{HP}$, 能率 $65 \mathrm{t} /$ 工, 二次火薬量 $230 \mathrm{~g} / \mathrm{t}$, 今後の改良 点としては，半長孔を下向のみでなく上向にも穿孔する ようにして，サブレベル間隔を大きくすることを，検討 中である。

\section{4. 運一搬}

露天掘の出鉱はシ ョベルでダンプトラックに積込んだ 鉱石を $800 \mathrm{~mL} り 550 \mathrm{~mL}$ まで通ずる坑井に投入し，大 峰，佐比内両坑では大部分が550m Lまで通ずる坑井に， 直接スクレーパで掻込むように計画されているが一部は 各レベルで中間運搬して本坑井に投入している。大峰, 佐比内両坑の主要運搬である $550 \mathrm{~mL}$ の運搬注 $15 \mathrm{t}, 10 \mathrm{t}$ トロリ一電車で $6 \mathrm{t}$ グランビ一鉱車に抜きとり新山鉱床 の $350 \mathrm{~mL}$ まで通ずる坑井まで運搬して，これに投入す る。

新山地区では，大部分が $350 \mathrm{~mL}$ まで通ずる坑井に直 接スクレーパで搔込むが一部は各レベルで中閒運搬をし て本坑井に投入する。

$350 \mathrm{~m}$ L の主要運搬は, $15 \mathrm{t}$ トロリ一電車で $12 \mathrm{t}, 9 \mathrm{t}$.グ ランビー鉱車に抜きとり約 $2,000 \mathrm{~m}$ の坑道を選鉱場へ搬 出している。

なお，各レベルの中間運搬は，6 tトロリ一電車また は， $6 \mathrm{t}, 8 \mathrm{t}$ バッテリ一電車で $6 \mathrm{t}$ グランビ一鉱車を 使用している。

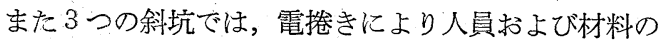
運搬をしている。

\section{5. 通気, 排水, 照明}

\section{$5 \cdot 1$ 通 気}

従来自然通気を行なつてきたが，2３年前より機械通 気を強力に推進し，現在では一部で強制通気を行なっ ている。すなわち新山北部と南部にそれぞれ通気専用切 上を設け60H, $150 \mathrm{H}$ の扇風機を使用しており，大峰坑内 でも601Pの扇風機を使用して強制通気を行なつている。 そのほか掘進やスクレーパ坑道などでは局扇による切羽 通気を行なつている。今後なお強力な主扇を設置すべく 計画中である。

\section{$5 \cdot 2$ 排 水}

排水は，自然排水で各レベルより の排水は斜坑また沏上をとおり各 地区の最下底坑道より坑外へ排水さ れている。坑内出水は少なく, 地表 水の侵入が大部分なので降雨の際は 排水量が急増する。

\section{$5 \cdot 3$ 照 明}

坑内稼㗢者注，全員キャップラン プを使用しているがそのほかに主要

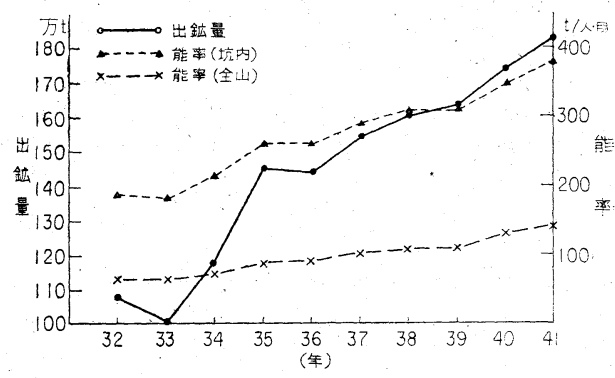

第 5 図

坑道には，20Wの螢光灯をその他の各所電灯を付けて いる。生た特殊な採掘切羽やスクレーパ積込切羽には， 投光器を使用している。

\section{6. 問題点之将来計画}

\section{A. 問題点}

（1）新山鉱床は，地表面まで宿没しているので 2 次採 掘の際ズリ混入による品位低下の防止に留意している。

（2）1次採掘の際の鉱柱を東，西両盤にわたる鉱壁と しているがこれの適正な幅と採掘幅との関係についての 問題

（3）採掘の大型化を順次実施しているが周辺部の小規 模切羽の合理的な採掘についての検討。

\section{B. 将来計画}

（1）切羽準備の急速化

○スクレーパ坑道の間口(ドローホール)，屋根造り の規格化

○切上掘進の急速化

○サブレベル掘進の急速化

○サブレベル坑道の上下間隔の拡大

(2) 長孔穿孔の全面 1 man 2 drill 化。

(3) 運搬における無線運転化。

7. 過去10年間の年間出鉱量, 平均品位およ び能率（坑内, 全山）の推移

（第8 表, 第 5 図)

\section{第 8 表}

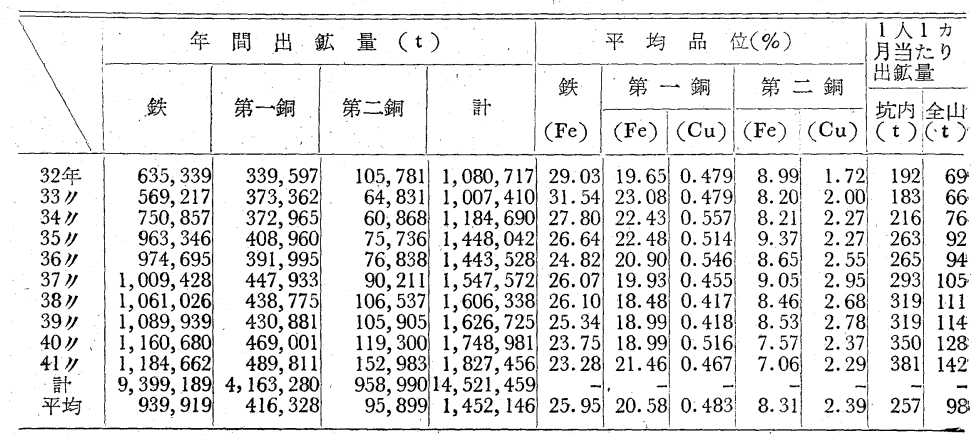

